\title{
Perennial War between the three tiers of Government in Nigeria: The Revenue Sharing Question Re-examined
}

\author{
Emma Chukwuemeka \\ Department of Public Administration, Nnamdi Azikiwe University \\ Awka, Nigeria \\ E-mail: ee.chukwuemeka@unizik.edu.ng Tel: 234-806-096-7169
}

\author{
Alexander Aniche \\ Department of Sociology/Anthropology \\ Enugu State University of Science and Technology \\ Enugu, Nigeria
}

Received: October 25, 2016 Accepted: November 11, $2016 \quad$ Published: December 22, 2016

doi:10.5296/iss.v4i2.10491

URL: http://dx.doi.org/10.5296/iss.v4i2.10491

\begin{abstract}
The relation between the three tiers of government in Nigeria has been problematic over the years. Several commissions and committees have been set and recommendations proffered, but up till today there is still fiscal conflict among the tiers of government. The local government being the third tier of government is the worst hit and this has resulted to inability of the local government to carry out its statutory functions effectively. It is in view of this that this study examined inter-governmental relation and the performance of local government in Nigeria. The study adopted survey design, specifically descriptive research was adopted. Data was collected using questionnaire, focus group discussion. Secondary data was generated from government records and Central Bank of Nigeria. The findings revealed among other things that inter-governmental relation has to an extent helped to reduce tension among the three tiers of government in Nigeria. Also the imperfection of 1999 constitution has hampered fiscal relation in the three tiers of government in Nigeria. The study recommended among other things that effort should be made to ensure that all tiers of government adhere to fiscal transparency, accountability and constitutional provisions on fiscal relations.
\end{abstract}

Keywords: fiscal responsibility, three tiers of government, local government 


\section{Mll Macrothink}

\section{Introduction}

Federation implies the existence of more than one level of government in one country each with different expenditure responsibilities and taxing powers. Nigeria is a federation consisting of states and federal capital territory, federal government, 36 states and 774 local governments. Among the different levels of government, fiscal arrangement ought to be worked out properly to ensure fiscal balance in the context of macro economic development and stability.

The fiscal arrangement among the different tiers of government in a federal structure contends (Osisioma and Chukwuemeka, 2007) is often referred to as fiscal federalism; in other types of political structure it is known as inter-tier or intergovernmental fiscal relations.

The capacity of the federal, provincial and territorial governments to assume their responsibilities hinges on the balance between decentralization of revenues and decentralization of government spending. This decentralization refers to the portion of total revenue collected and expenditures allocated to both state and local governments. The degree of decentralization argues Okoro (2006) is the extent of independent decision making by the various arms of the government in the provision of social and economic services. It connotes the degree of autonomy of state and local governments in carrying out various economic tasks.

Vincent (2002) enumerated the existence of the following fiscal arrangements before the military took over power in 1966.

- The regions were assigned the proceeds from export and excise taxes while the Federal Government received the share attributable to Lagos area.

- Marketing boards were regionalized and their respective regions retained their operational surpluses.

- Regions were empowered to fix produce prices and also impose tax on the produce of the marketing boards

- Regions were assigned the full retention of mining rents and royalties with a federal tax of $30 \%$ payable to the distributable pool account (DPA) and were later adjusted to 35\% in 1957.

- Regions were allowed to administer and retain income tax on incomes not above $\$ 700$ per annum.

- The federal government collected import duties and corporate income taxes.

- The regional governments determined the relationship between the regions and the provinces.

The implications of these measures were an increase in regional revenue from $17.7 \%$ in $1945 / 49$ to $41.6 \%$ in $1966 / 67$ while the share of the federal government declined from $82.3 \%$ to $58.4 \%$ in the same period (Obasi, 2006). The military intervention in 1966 brought new changes as the federal constitution of 1963 was suspended. The Federal Government took over state and local government functions. Consequently, new tax measures were introduced as follows: 
* The transfer of legislation and administration of mining rent and royalties to the Federal Government.

* Centralization of the marketing boards while all taxes, surpluses and fixing of produce prices were administered by the Federal Government.

* Right to revenue emanating from company income tax, import, export, petroleum profits tax (PPT), excise tax and mining royalties and rents were vested in the centre

* Introduction of uniform rates in personal income and sales taxes while the state was to administer the taxes.

* Replacement of sales tax with value added tax (VAT) in 1994 and subsequently transferred to Federal Government for the purposes of regulation and administration while the proceeds are paid into the VAT account for distribution among the tiers of government. Subsequently, the revenue potentials of the states were eroded, and internally generated revenue between 1993 and 1999 stood at $74 \%$ of total revenue while that of the local councils between 1996 and 1999 averaged $67 \%$ of total expenditure (Ezeabasili, 2006).

\section{Statement of Problem}

The issue of having an acceptable formula for sharing resources among the three levels of government in Nigeria has remained problematic. A cursory look at the issue shows that the issue has resulted to tension and fight among different federating units. Different Commissions and Committees had come out with different formula but that has not solved the problem. Conflict has become very common among federating units in the course of fighting for fund. For instance, the conflict is usually whether the principle of derivation, need, natural interest or landmass should be used as a basis for the purpose.

There is the problem of tax jurisdiction, which refers to the problem of which aspect of government should collect what revenue over a particular area. These have been serious problems between the Federal, State and Local Governments. Their share of tax revenue seriously affects local governments. They are the lowest level of government. Likewise they collect the least amount of tax revenue, which makes them still stagnant.

Also there has been an occasional drop in amount and delays in remittances of federal allocations which left some strains in the financial capacity of the local government to prosecute some policies and vital programmes.

The practice of federalism without recourse to true fiscal federalism amounts to sheer hypocrisy. The fact that the basic issues in Nigeria's fiscal federalism are still hazy has equally encumbered her progressive move towards a true nation state. During the pre-independence period, a number of commissions were set up to look into the problems of Nigeria's fiscal federalism. These include: Philipson Comission (1946), Hicks-Philipson Commission (1950), Lenis-chick Commission (1954), Raisman - Tress Commission (1958).

However, notwithstanding the fact that each tried to resolve the controversy surrounding true fiscal federalism in Nigeria, the issue persisted. This culminated in the series of other 
post-independence commissions that were equally set up to provide the needed panacea on fiscal federalism arrangement for the country. These included: Bins Commission (1964), Interim Revenue Allocation Review Committee (1969), Obigh Commission (1979), Danjuma Commission (1988) etc. Given the scenario, when the country reverted to the democratic rule in 1999, the 1989 constitution was made operational with several attempts to address the plethora of problems associated with the country's fiscal federalism. However, during this period, there existed quite a lot of controversies surrounding the nation's fiscal practice that led to some states in the Niger Delta region taking the Federal Government to court ( Olugbemi (2000).

\section{Objective of the Study}

The broad objective of this study is to critically evaluate intergovernmental relations and performance of Enugu State Local Government Councils. The specific objectives therefore are to:

(1) Evaluate the relationship between the federal, state and local government in the area of Performance of the local government.

- evaluate the agitations/complaints by the lower tiers of government vis-à-vis the principles of true federalism

(2) To examine the constitutional provisions of revenue allocation and analyze its implications on the lower tiers of government

\section{Hypotheses}

(a) There is a relationship between the problem of revenue allocation in Nigeria and the Performance of the local government councils

(b) Imperfection in the 1999 constitution of Nigeria has hampered good intergovernmental relations.

\section{Methodology}

The study adopted survey research design. Fifty seven respondents formed the sample for the study. The sample had diversity in terms of age, sex, social economic status, and experience among other variables. Questionnaire items were used to source data from the respondents. The items sought to which the respondents understood the problem of inter-governmental relations in Nigeria as they were conceptualized in the literature review. The questionnaire was pilot tested and rated highly by raters with extensive experience in the use of the instrument for research purposes. The ease of access to the respondents by the researcher, allowed for a personal administration of the instrument which ensured hundred percent return rates thereby eliminating non-return bias. In depth interviews were conducted with the 57 respondents as a follow-up to the questionnaire in order to glean the subtle aspects that questionnaire items could not adequately elicit. Interviews focused mainly on the respondents' justifications for particular response options to questionnaire items. 


\section{Literature Review}

\subsection{Conceptual Framework}

Intergovernmental relations can be defined as the interactions that take place among the different levels of government within a state. Usually, the concept is associated with states having a Federal administration system where the relationships between the Federal, Central or national Government and the major sub-national unit (province, region or state) are formally spelt out in the constitution and any re-arrangement must be through a constitutional amendment involving all the levels of government. Although, the emphasis in the analysis of inter-governmental relations (Inter-governmental Relations) is on Federal-State Relations, the full picture also includes how both levels relate to the Local Government units established within each state. The result, then, is that a full analysis of inter-governmental Relations within a Federal administration system must cover the following: Federal-State, Federal-State-Local, Federal-Local, Inter-State, State-Local and Inter-Local Relations (Ralph 2004).

The definition and sharing of the State as well as the resources to accomplish such goals is the primary thing in such democratic system, inter-governmental resource sharing is normally done in the basis of perceived importance, coverage and capability of each level of government and especially in Federal democratic systems, it is enshrined in the country's constitution. Secondly, another objective of the inter-governmental relations is bilateral or a multitude of pursuits of conflicting self-interest in the areas of first business undertakings, personnel and information exchanges, grants of extra-territorial rights in service delivery and the pooling and co-ordinations of resources and efforts, aimed at attaining greater economy and effectiveness in operations (Ofoeze, 2002).

According to Adamolekun (1983), this is the interaction that takes place among the different levels of government within a country. In concept of Inter-governmental Relations, as earlier stated, is not the same thing as Federalism. While no single definition of Federalism is generally accepted, it can be described as the contractual and Legal Status between the national (Central) government and the states and to some extent between both the national and state governments and localities. While Intergovernmental relations, however involved the range of interactions among all types land levels of government (Bingham \& Hedge, 1991)

In a unitary state, inter-governmental relations would be referred to as the interactions between the national government and the sub-national governments. However, the constitutional allocation of governmental functions between Federal and regional governments in a Federal system is absent. It is the central government that determined which function is allocated to the sub-national governments. The central government can also decide to modify the functional allocations without consulting the lower units. Furthermore, the central government in a unitary state can unilaterally determine both the substance and the style of inter-governmental interactions (Adamolekun (1983).

This kind of jurisdictional interaction, separation of powers or constitutionalized mechanisms of checks and balances do not exist in a unitary or totalitarian system of government, because of in-built systematic contradictions. In such systems of government, the subordinate levels of 
government are glorified level of authority or mere rubber stamps. They lack actual jurisdictional powers and/or autonomy to determine what role to assign to the subordinate levels of government and the central government can decide to alter its decision without the consultation of the subordinate governments.

This does not mean that in a unitary system of government we do not have measures of inter-governmental relations but a basic point to note here is that such subordinate government does not have the same attitude of freedom as a Federal System would offer (Adamolekun, 1983).

In essence, inter-governmental relations can be seen as relationship between all levels of governments within a political system. Inter-governmental Relations is a federal System, like Nigeria, has taken an important dimension in recent time due largely to the concern now given to the importance of cooperative Federalism as well as the fading away of dual Federalism. Dave (1980) noted that inter-governmental relations admit that the constitution cannot spell out all relations in a Federal system and that division of duties and responsibilities cannot be absolute. He also believes that inter-governmental Relations refer to the whole array of activities intended to iron out the conflict inherent in a Federal arrangements and that it stands on the premises that force, coercion or confrontation may be counterproductive.

\subsection{Administrative Mechanism for Managing Inter-Governmental Relations}

In some federal administration systems a member of administrative mechanisms have devised for managing inter-governmental Relation. In Canada, for example, the emphasis is on the use of periodic conferences of political leaders and appointed officials. This approach is also a common feature of intergovernmental relations in a few other Federal systems such as Australia, Nigeria and India. In each of these countries, the two major subjects for discussion are Finance and Economic policy.

Making reference to Canada, the most important conference is the annual premiers' conference. Matters relating to finance and economic policy usually dominate these conferences. During the past two decades the number of meetings and conferences at the level of both political leaders and administrators had increased tremendously in addition to meetings involving Federal and provincial and provincials-local relations. By the late 1970s the Federal Government has established rank called the Federal Minister for Inter-governmental Relations (Admolukun, 1983).

Okoli \& Onah (2002) however, brought the issues home to Nigeria, when they asserted that inter-governmental administrative relations are constitutional machineries established in Nigeria for the maintenance of inter-governmental relations. Some of these institutions include the National Economic Council, the National Council of States, the Liaison Offices; the State Local Government staff etc. there has also been series of conferences organized for leaders and officials of the various levels of government. Virtually, every aspect of government activities has been covered by either, Federal-State or inter-State conferences or combination of the two. Conferences have continued to be the greatest for inter-governmental relations in the Nigeria context, but besides that, some machinery have help matters. The existence of such offices as 
the special Assistance to the Governor on Local Government matters is a State (such as Enugu) ensures a State-Local Relation. The membership of state appointed members to the local Government service Commission has been another way of ensuring these inter-governmental relations.

Conferences as mentioned above, constitutes the major tool for managing inter-governmental relations. Hence, (Okoli and Onah 2002:124), observed that between 1989 and 1981, there were over two hundred conferences and meetings held at both the Federal, State and Inter-State levels. Some of these conferences they continued include:

(i) The Bi-annual conference of Commissioners for Local Governments

(ii) The National conference of the Ministers and Commissioners for Finance.

(iii) Meetings of Secretaries to Governments of the Federation.

(i) The National Conference of Ministers and Commissioners

(ii) Meeting of Accountants-General of the Federation

(iii) Meetings of Civil Service Commissioners of Oyo, Ondo, Ogun, Lagos, Edo States

An interesting question is the extent to which officials at the Federal, State and Local levels engage in hierarchical (meaning superior subordinate) and bargaining - negotiating patterns of relationship. The dominant pattern is like to change from time to time and the crucial factors at any given time will most certainly include; the relative position of each level of government in the intergovernmental Relations system, the behavioural pattern of the political actors and the quality of staff available at each level of government (Ralph 2004:196).

\section{Inter-governmental Relations in Nigeria}

The dynamics of the Nigerian Federation and the Nigerian Constitution make IGR a political imperative. With over four hundred lingo-cultural groups, a population of over 120 million, thirty-six state and a Federal Capital Territory and 774 Local Government, IGR in Nigeria inevitability, over the years the pendulum of Federal associations among groups has swung between centrifugal and centripetal forces, as Nigeria sought to adjust the Federation.

As Nigeria used the framework of Federalism to manage her conflicts, she has found that intergovernmental relations is a necessary mechanism to promote cooperation, manage conflicts, respond to changing circumstance and deliver services more efficiently. Intergovernmental Relations is basically a mechanism for managing conflict and delivering services. Institutions and processes of Intergovernmental Relations services to;

(i) Promote Co-operation among Governmental Units

(ii) Recognize and manage conflicts

(iii) Deliver services more efficiently and

(iv) To respond to changing circumstances. 


\section{MInstitute Macrothink $^{\text {Int }}$}

Formal and constitutional institutions also exist for IGR in many Countries as well as ad-hoc meetings among members. There are institutions and processes of IGR and they include constitutional constitution, statutory institutions and Informal/ad-hoc institutions. There have changed over times, depending on the Constitution and the system of government in operation.

Looking at the constitutional institution, these are constitutionally provided institutions of IGR and they include;

- The National Assembly - Section 4(1) of the 1979, 1989 and 1999 constitutions state clearly that 'there shall be a National Assembly for the Federation which shall consist of a Senate and a House of Representatives. Representing the whole Federation on the basis of population in the (House of Representatives - HOR) and on the basis of equality of states (in the Senate), the National Assembly in an open legislative institution of IGR. It is powers of legislation over appropriation bills control over public funds, contingency fund and investigation all makes the National Assembly an important inter-governmental institution in the constitutions.

- The Supreme Court has the final power of arbitration in civil, criminal and constitutional matters. In Nigeria's Second Republic, State Governments took the Federal Government to court over revenue sharing formula and the Agricultural Development Basin Authorities. Individuals and Corporate groups also went to the court to seek redress.

- The council of States - This is essentially one of the advisory executive bodies contained in the constitutions of 1979, 1989 and 1999. Its functions include advising the President with regard to the conduct of national census, prerogatives of mercy, award of national honour, the Independent Electoral Commission, the National Judicial Commission, the National Population Commission and on public order. The membership of this body also reflects its intergovernmental nature.

- The Federal Character Commission is another constitutionally guaranteed executive IGR's agency. The functions of this agency include working out equitable formula for the distribution of all cadres of posts in the Federal and State public services, promoting, monitoring and enforcing compliance of proportional sharing of public offices and taking measures to enforce such compliance. Given various complaints about injustices/unfairness in the distribution of public services positions among components units of the Federation, the importance of this commission cannot be over emphasized. This agency is expected to carry out the constitutional provisions in Section 14(3-4) of 1979, 15(3-4) of 1989 and 14(3-4) of 1999 constitutions which states that the composition of the government of the Federation or any of its agencies and the conduct of its affairs shall be carried out in such manner as to reflect the Federal Character and the need to promote national unity.

- The Independent Electoral Commission (INEC) has the functions of organizing, undertaking and supervising all elections. There is a provision for State Electoral Commission in each state of the Federation. It also has the function of registering 
political parties, monitoring the organization and operation of political parties and annually examining and auditing of the funds and accounts of political parties. This commission registered the three political parties. The Peoples' Democratic Party (PDP), the All Peoples Party (APP); and the Alliance for Democracy (AD) which formed the crux of Nigerian's Fourth Republic from May 29, 1999.

- The National Economic Council (NEC) has the powers to advise the President concerning economic affairs of the Federation and in particular on measures necessary for the coordination of the economic planning efforts or economic programmes of the various governments of the Federation.

- The National Judicial Council has the power to recommend appointments to the bench at Federal and State levels and FCT. It can also recommend the removal from office of the judicial officers and exercise disciplinary control over members of the judiciary.

- The National Population Commission has the functions of undertaking periodic enumeration of population through sample surveys, census etc, continues registration of births, deaths, advising the president on population matters and providing data/information on population for National Planning and development.

- The Revenue Mobilization Allocation and Fiscal Commission is responsible for monitoring accruals to and disbursement of revenue from the Federation account. Periodically reviewing the revenue allocation formula and principles in operation to ensure conformity with changing reality advising federal and state government on fiscal efficiency and methods by which their revenue can be increased and determining the remuneration of the President and Vice President.

- All these executive IGR institutions are constitutional. The long period of military rule "froze" the activities of some of these agencies but they are again operational. Ironically, many of these agencies were created by various military administration but they are now operating fully to carry out their mandates.

STATUTORY AGENCIES are inter-governmental institutions that are backed by law and most of them were established under military rule. This is evidence that even under the military's hierarchical structure of authority, it was still necessary to establish institutions of IGR in order to resolve conflicts and or deliver services. Among such IGR institutions are:

1. The Directorate of Foods, Road and Rural Infrastructure (DIFRRI) to open up; rural areas, provide essential services such as water supply through boreholes, rural electric power supply and roads. Essentially, this programme was aimed at making the rural areas more attractive and thereby reducing the rural-urban drift. Rural development is really the function of state and local governments. Since the Federal government's intervention as these areas was deemed necessary, DIFRRI was established as IGR institutions. State governments were to contribute $25 \%$ of the total fund for DIFRRI projects while the rest came from the Federal Government. While DIFRRI headquarters managed the funds, state governments and State DIFRRI offices (under State Governments) execute these projects. 
Between 1986 and 1989, DIFRRI has opened up 30,000 km un-tarred road to rural communities, supplied portable water to 250 communities and had reached advanced stages of installation of rural electrification in 227 Communities. This agency exhibited successful performance for about five years, after which it become bureaucratized and suffered from corruption on the part of the operators at state and local levels.

2. The National Council on Inter-governmental Relations (NCIR) was established July 1992 to closely monitor the operation of the Federal System, giving continuing attention to inter-governmental relations in the Nigerian Federal System, study conduct research and maintain data, recommend solution s to problems of inter-governmental relations and necessary forms of improvement, play mandatory roles in resolving conflicts and establish contacts with other organizations with similar objectives. A major problem of NCIR was bureaucratic suffocation, which even starved it of funds. In addition, NCIR had no independent source of funds that was necessary if it was to mediate among tiers of government and to remain neutral.

Some other institutions of IGR under Statutory institutions include: Boundaries Commission The National Directorate of Employment (NDE); The National Planning commission and the National Primary Education Commission.

Under the Ad-hoc or Informal bodies and Agencies; they are useful in bringing together Federal, State and Local Officials in a particular policy area. They also help to smoothen intergovernmental relations and encourage co-operation among component units of the Federation. The various National Councils in Education, Agriculture, Health, Industry, Information, Tourism and Finance are usually meetings among Ministers at Federal and State levels to bring State and Federal political executives together to harmonized policies in the interest of the Federation.

All the above institutions of IGR are important in managing conflict and responding to changing circumstances in the Nigerian Federation. While IGR institutions are useful, they also carry with them the baggage of their own problem, which need careful attention. Some of the tension, which arise in the Nigerian Federal, emanate from the overlap of functions among tiers of government. They are derivable from the kind of pulls, the tension arising from attempt at delicately striking a balance between centripetal and centrifugal forces. These become very evident in the relations between Federal and State governments, State and Local Governments and even in the relations among state governments. (Isawa, 2005).

There is provision in the 1976 constitution of the Federal Republic of Nigeria at the Second schedule of the constitution of the formal division of power between the Federal and State government with defined functions in section $7^{\text {th }}$ and $4^{\text {th }}$ schedule of constitution respectively. The independent form given to these levels therefore did not mean that there shoed be no relations among the levels of government in Federal Republic of Nigeria. Since 1976 when the Nigerian Local Government Reform come local Councils a uniform posture and the constitution that come subsequently (in 1979) recognized it as the third-tier system of government, the story had remained the same. 
In the present democracy, the local governments are assigned roles and functions partakers in the inter-governmental relations which makes hitherto prevail existed between only the central and state or regional government alone. At the end of the reform of the local government and the consequent execute olfaction of the officials in the Council level. Annual conferences of chairmen of Local Government in Nigeria started off. Also, the bi-annual conference of Commissioners for Local Governments and creation of an executive office of special Assistant to the Governor on Local Government matters etc all as avenue or for inter-governmental relations between the local government levels and other levels or among local governments started off. Hence the new local government system in the new democratic Nigeria, in all its fundamentals has redefined;

(i) The power-relations between the states and the Local Governments

(ii) The power relations between the state and the Federal Governments in their combined relations to the government and

(iii) The relationship between the local government and Federal Government.

Having reviewed the evolution of the institutions and processes of IGR and inter-governmental interactions, essentially in terms of the relations among the levels of government; Nwatu (2004), argues that it was necessary to emphasize that a full analysis of intergovernmental relations must also focus on the ordinary citizens reactions and o the activities of the public official who operate at the different levels of government. Also the attitudes and roles of both political leaders and appointed officials at the different levels of government throughout the period under review (1954-81) have significantly influenced both the substance and style of Inter-governmental Relations in Nigeria. (Ralph 2004).

\subsection{Assessment of Fiscal Assignment in 1999 Constitution}

The devolution of power in any federal arrangement derives from the vertical division of resources base and expenditure obligations. In most cases, the allocation of functions is dictated by the rule that the federal government should handle responsibilities whose spillover effects are national in character. While the states and local authorities perform those functions whose benefits are local.

In a federal system of government, the functions and responsibilities of each tier of government are specified in the constitution. The exclusive legislative list consists of items on which only the central government could legislate. A concurrent list contains items on which both the state and the federal could legislate. However, in case of discrepancy, the power of the central government supersedes on these items. Other residual items not stated are left for the local councils to legislate.

The second schedule, section 4 of the 1999 constitution addresses the division of powers between the federal and state governments and the local councils as well as the taxing power and revenue sharing. Under these provisions, functions assigned to the states are residual powers explicitly not assigned to the federal government (Sani, 2003). 


\section{Macrothink}

Table 1. Assignment of responsibilities in the 1999 constitution

\begin{tabular}{|lll|}
\hline Federal Government & State Government & Local Government \\
\hline Defense and National sec. & Higher Education & Sewage disposal \\
Police & Secondary Education & Environmental sanitation \\
Foreign Affairs & Primary Education & Maintenance of Fed. earth roads \\
Inter-state roads & Primary Education & Primary education \\
Mineral exploration & Urban and rural waters & Payment of salaries \\
International Roads & Transportation & Payment of salaries \\
Railways & Housing & Payment of salaries \\
Airports & Health & \\
Aviation Facilities & Lighter industries & \\
Power supply & Agriculture & \\
Communication & Tourism and Town & \\
Management of Territorial & Planning & \\
Waters & & \\
Higher education & & \\
Secondary Education & & \\
Tertiary education & & \\
Agriculture & & \\
Commerce and Tourism & & \\
\end{tabular}

Source: Ezeabasili in Sanni, G.K (2003) Emerging Fiscal Issues in Bullion 27(3) 9-10

The pattern of responsibilities by the constitution has raised some fundamental issues, which are:

- Functions with high rate of returns such as power supply, port management are assigned to the federal government while functions that are of social assistance with low economic rate of return are assigned to the states and local governments.

- There is no defined role between the federal, state and local government clearly stating responsibility in respect of many conflicting functions such as education and health.

The lopsidedness in the fiscal assignments resulted in intense agitation for fiscal decentralization and resource control that subsequently led to the controversy on on-shore/off shore dichotomy.

\subsection{Supreme Court Judgment on Revenue Allocation}

The major highlights of the Supreme Court of Nigeria judgment on revenue allocation as contained in SC/28/2001 of $5^{\text {th }}$ April, 2002 are as follows: 
(a) The deduction of the first line charge, from the Federation Account for debt servicing before payment of the $13 \%$ revenue on derivation to the oil producing states is unconstitutional and void.

(b) The under listed economic policy and or practices of the Federal government are unconstitutional being in conflict with the 1999 constitution:

- Exclusion of natural gas as constituent of derivation for the purposes of the provision

to section 162(2) of the 1999 constitution

- Non-payment of the share of proceeds from capital gains and stamp duties.

- Funding of the judiciary as a first line charge.

- Servicing external debts via first line charge on the federation account.

- Funding of joint venture contracts and Nigeria National Petroleum Corporation (NNPC)

priority projects as first line charge from the federation account.

- Unilaterally allocating one percent of the revenue accruing to the federation accounts

to the Federal Capital Territory (FCT) (Sanni 2003, Ezeabasili, 2006).

\subsection{Matters Arising From the Court Judgment}

The implications of the judgment on Nigeria Fiscal Federalism are multifarious: They include:

- The share of revenue to the states and local councils will be enhanced due to the stoppage of deductions of first-line charges while the share of revenue to the federal government will reduce.

- The extension of derivation principle to process from natural gas will also increase the share of revenue going into the coffers of oil producing states. It is illegal for the federal

Government to deduct from statutory allocation of the local councils, the provision for the maintenance of the primary education, which was usually the major cause of "zero allocation" to some council.

- The judgment restored the operation of joint account by states and local governments but this is likely to be confronted with many problems. First the release of the share of allocations to local governments by their state governments would be based on political patronage. Second, the operation of the joint account may be used as a weapon for political vendetta against recalcitrant local government chairmen. Also, there is a likelihood of fund diversion and undue interference in the running of local councils by their parent states, local councils would technically cease to be "autonomous" since they will rely more on the state governments for everything they need. The operation of joint account will perpetuate mismanagement and corruption since federal control has been removed. The resultant effect of all these is that development, which is the basic reason for creating local councils, would be a mirage. The 
chairmen are likely to be accountable to the state governors rather than the electorates who elected them (Sanni, 2003).

\section{Inter Governmental Relations and Local Government Administration in Nigeria}

The effects which, intergovernmental relation has on local Government Administration in Nigeria can be considered under the following points:

(1)RESOURCE DISTRIBUTION - Government decision as to who gets what, where, when and how thus becomes a distribution issue. Equity in the distribution of resources becomes necessary if conflicts are to $b$ e avoided. As individuals or groups compete to maximize their share of scare both allocatable resources, conflicts easily emanate, requiring urgent attention to ensure the smooth operation of the system. Distribution of resources however must address two issues:

(a) The increase in the production of allocatable resources (the supply side)

(b) The nature or basis of the distribution of these resources among groups

(the demand side).

Distribution of resources is important because it is a determinant of the pattern and the nature of development among sub-national units. Efforts must be made to avoid over-concentration of resources in few "poles of growth or centers" of strength of maximize short run capacity in order to avoid crisis. (Isawa, 2007).

Resource distribution issues in a Federal, also give rise to a conflict between capacity and equality among the various units which form the federation. As (Elaigw 2007) explained the situation, "the conflict between capacity and equality for a Federation may be seen as the overall development of a country on the one hand and even development among sub-national units of a federation fork purpose of political stability.

So in this case, local government due to the power given to it through the constitution has it own autonomy share of resource distribution which helps it develop rapidly. Equity in the distributive process calls for equalization of income through transfer. This implies that it is the obligation of the Federation to see to it that the citizens of each state can enjoy a given minimum level of public services. If anyone state or local government is too poor to provide this minimum level even though a required minimum degree of tax effort is made, the Federation steps in. These have had a positive effect on local government administration in Nigeria leading to its growth and development. (Ralph 2008:62).

(ii) GRANTS - Grants are also made where these is no intention to interfere with local choice, the objective being one of fiscal equalization. Some jurisdiction (State or Local) enjoy a high taxable capacity (i.e. the tax rate needed to obtain a given level of revenue is low) and have a relatively low level of need (i.e. the amount required to provide certain service levels is small). They are thus in a fiscally strong position, as measured by the ratio of capacity to need, others are in the reverse position. The central government may then wish to equalize fiscal position through various ways. The central government may wish to secure common minimum levels 
and adjust its grant ;policy to secure this objectives, the central government on the other hand may wish to equalize actual service levels and for this purpose impose such matching grants (where to levels) or taxes (where needed to lower levels) as are required to secure equalization (Nzue 2009).

Again, due to inter-relationship between the three tiers of government, local government receive grants from the State Government, Federal government, Banks and other Financial institutions that will help develop local government administration as a whole.

(iii) REVENUE SHARING AND ALLOCATION: Revenue sharing and allocation is one of the most important examples of inter-governmental grants. In this case, since 1946, revenue allocation has continued to dominate the arena of IGR in Nigeria culminating in intergovernmental conflicts. The process of colonial reconstruction of Nigeria began with the adoption of regionalism itself immediately raised the question of acceptable formula. For revenue allocation between the central government and the constituent units like the local government.

The dialectics of revenue allocation and the complexities of the indices that have been used in arriving at acceptable formulate have generated so much controversies (conflicts) and disenchantment with the result that the promises that the Nigeria nation held at independence have been dinned and diminished by the reverberations emerging from perceived inequity generated by the various formulae that have been used and discarded, one time or the other (Nzute 2009).

The search for an acceptable revenue allocation formular has led to the adoption of several principles and economic indices that have in various combinations been used, faulted, discarded and reinvented through the instrumentalities of revenue allocation commission such as Phollipson's (1946), Hicks Philipson's (1951), Raisman's (1958), Binns' (1964), dina's (1968), Abonade's (1977) and Pius Okigbo's (1980) commissions.

To that effect, struggle for the allocation percentage between the Federal, State and Local governments has been in it high rate. Where the Federal will like to take k50\% of the allocation, state $30 \%$ and local $20 \%$, the state and local might be feeling that the Federal has cheated on them, then the struggle continues. (Asogwa 2009).

Intergovernmental interact on may reduce the problems associated with inter-tier conflicts. Under the Obasanjo administration, state and local governments were treated as virtual extensions of the Federal Government. Some of the available conflicts in the Federation under - the fourth Republic device from the hangover of the military regime in which the center has grown titanic curbing the unnecessary adventures of the center have become a problem. There are many arenas of cooperative intergovernmental relations. Politicians at this stage of Nigeria's development are either ill-equipped to deal with these problems or are un-willing to establish normal inter-governmental relations even when constitutionally provided. Like most things in nation states, there is a need for mutual compromise to enable fairness, justice and relative equity to lubricate the wheels of the Federation. It is hoped that with more discussions 
and collective experience, the polities of distribution will not be a danger to the Federation. (Elaigwu, 2009).

Moreover as increased pressured are exerted on the limited resources of the nation, how these resources of the nation, how these resources are shared among competing components of the Federation will continue to be called to question. All tiers of government need resources to survive. As demands are placed on each tier of government the struggle for more equitable resource sharing formulae will continue.

The principle of derivation as basis for revenue sharing will increasingly be emphasized because of the needs of the various components of the Federation and the desire to have greater control over resources by the various components of the Federation. The various principles that are currently used become obsolete. As an incentive to ensure greater generation of revenue by the various tiers of government, derivation will be given more emphasis. This can augur well for the nations as each component of the Federation will work hard to generate more internally derived revenue, thus reducing the over dependence on Federation Account. This is a very probable positive development in the future. The over-concentration on Federation Account will need to be reduced as a matter of necessity. In fact, the measure of development of the States would be determined by how much revenue they are able to raise internally. The current unhealthy situation of over dependence on Federation Account cannot continue to be allowed or be encouraged (Elaigwu, 2007).

Moreover, for grassroots development to take place it would be necessary to pass on more resources to the local government tier of the Federal structure. But this will require more stringent measures and increased accountability of the use of funds at that level. The current projects, which give, rise to development at the grassroots levels must be addressed. (Ralph 2008).

Due to the effect inter-governmental relations have on local government, they were able to generate resources from cottage industries and other productive activities rather than depending on market levies as the principle sources of revenue. But the weakness of these impacts is that local government with few markets cannot raise much revenue. Alternatively, the local people get over taxed in an effort to raise revenue level.

Thus, resource sharing must address the necessity for rapid development at the grassroots level. As development gets entrenched at the grassroots level, the Federal level will invariably relinquish some of her activities. This will necessitate re-organizing the resource sharing structure (Sylvanus, 2009).

For development to take place especially at the grassroots levels, horizontal distribution is very crucial. The efficiency in the use of funds at that tier of government must be increasing effected in order to move the nation forward. The clamor for development, especially on the area of poverty reduction can best be achieved through a combination of effective vertical and horizontal distribution of revenue. The formula for revenue allocation has always been an important factor in ensuring that the relationship among the tiers of government in a federation is stable and that every level experiences a sense of satisfaction. (Ojo, 1989) in discussing 
revenue allocation formula in Nigeria had this to say: Nigeria has experience not less than ten formulae and a number of commission set up to look into the matters. In some cases, the reports were rejected mainly as a result of protests from the units of the Federation either because too much of the revenue was allocated to the center or the wrongs principle was employed in arriving at the formula.

The important of the abode assertion is that revenue allocation formular in Nigeria has been a matter of controversies and politics thereby making fiscal Federation a dominant feature in the arena of intergovernmental relations.

Borrowing is an option for any tier of government whose expected expenditure exceeds its expected revenue. The Federal Government can borrow domestically and from abroad. State government can borrow domestically, they can also borrow externally but only with the prior approval of the Federal Government. The local Government Councils can only borrow domestically. Generally, states and local governments are expected to borrow to finance capital projects only. Local government borrows from other levels of government due to the relationship that exist among them (Isawa 2007).

(iv) ADMINISTRATIVE RELATIONS - (LEGISLATIVE - EXECUTIVE) - Due to the relationship between the three tiers of government, state governments are vested with the powers to "enact through the state House of Assembly a law providing for the structure, composition, revenue. Expenditure and other financial matters, staff meeting and other relevant matters for the local governments in the states" subject to the provisions of the constitution. The state government established a Joint Planning Board through a law enacted by the State Assembly (Okoli \& Onah 2002).

The law provided for the participation of every local Government within the state in the economic planning and development of the local Government area. The National and State Assemblies are empowered by the constitution to legislate on the creation of new states and adjustment of state boundaries also requires a legislative approval of the local government Councils in the State concerned. The state executive possesses the power to institute a Panel of inquiry into the operations of any local government which does not perform satisfactorily and give appropriate punishment to offenders. He is also empowered to dissolve a local government council if the council fails to discharge it functions effectively and can appoint a caretaker management Committee to discharge its functions. The local Government (Basis constitutional and Transitional Provisions) Decree 1980 has gone far to provide that the President possesses the power to remove any chairman of the Local Government or dissolve the Council and appoint a caretaker Committee to manage the affairs of the Local government until an election is held (Ralph 2008).

In spite of the 1976 local Government Reform, all the measure taken to guarantee their autonomy, local governments still remain in theory and practice, part and parcel of the State in which they exist. With regard to administrative relation, the Ministry of Local Government, as an Agency of the state government before it abolition in 1988 exercise stringent controls on all the activities of local Governments. All the bye-laws of the local Government Council were approved by the Ministry of Local Government before they came into force. Bicycle plates, 
revenue receipt books, death and marriage certificates were provided centrally by the Ministry (Ralph 2008)

The annual estimates of the local governments were subject to approval by the Ministry before they were implemented. The Ministry approved major contracts of the Local Governments before they were awarded. The Ministry exercised very powerful control of local governments through its inspectorate division, which provided inspectors who visited local governments regularly to inspect their operations in order to ensure that officials and councilors complied with law and regulations. The State Government provided local governments with Financial memorandum which guided their financial management. The Ministry also imposed adoptive bye-laws to Local Government whenever it was deemed necessary (Nzute 2009).

Some chairmen of Local Governments and Councilors of the Second Republic were not happy with these excessive control measures exercised over the local government by the State Government. They argued that while the State Ministry of Local Government was a necessary clearinghouse and coordinating center of the activities of the local governments, it had in many ways constituted a hindrance to development and progress (Ralph 2008).

(v) FUNCTIONAL RELATIONSHIP - The constitution of the Federal Republic of Nigeria 1979 provides for two sets of local government functions: executive and concurrent. The concurrent functions include primary education, health services and agricultural extension services, industrial and commercial services. In these concurrent functions, the local governments provide them in conjunction with state and Federal Governments. Often the Federal/State Governments provides the financial resources, in part or whole, while the local governments provide local managerial resources, local political control, supervision and community support. The State Government can prosecute any of the functions jointly with the local governments. It possesses he power to delegate any of its functions to local governments to perform under its supervision and control. Moreover, the constitution provides that the state Assembly can, through law confer upon the local Government 'such other governments, as their universal primary Education and the National Health Schemes.

Finally, the Federal and State Governments prosecute Community Development programmes with Local Governments. For instance, the Directorate for Food, Roads, and Rural Infrastructure (DFRRI)/State Directorate for Rural development Work with local Governments in executing their projects. (Ralph 2008).

(iv) STAFF MATTERS - Local Government also relate with State and Federal Governments on staff matters. The local Government Service Commission is responsible for the appointment, transfer, promotion, discipline and training of local Government staff. The Federal Government also provides staff training funds and programs for training of local government staff. The Federal Government provided an Approved Scheme of Service for the Local Government which now governs the local Government Services. It also prided the pension scheme and fund, which are enjoyed by the staff qualified for them. The Governor of a State Government holds together regular talks and consultations with chairmen of Local Governments on vital issues of security 
and general development of the state. He also visits local government areas where he and his officers interact with local Government Officers on their needs and problems. (Ralph 2008).

In the same way, state Government Commissioners and officials undertake working visits to local government areas where they interact with local Government officers and Councilors on the affair of the area. On the other hand, local Government Chairmen hold regular consultations with the Heads of Federal and State Government Ministers and Departments in the area with a view of recurring their co-operation, coordinating their activities and giving the necessary advice and assistance to their needs and problems. (Ralph 2008).

As local Government are units that make up the states which exists in the federation, each level of government is concerned with the task of public security and public welfare, hence healthy and coordinal inter-governmental relations are is indispensable factor for good Government and rapid development. (Okoli \& Onah 2002).

\section{Statutory Allocation}

Statutory allocation contends Eze (2015) is share of revenue from the Federal to the State Government or Local Government as fixed by law. It comes into existence in order to replace block grant because of its inadequacies. Statutory Revenue Allocation was first introduced in Nigeria by the Local Government reforms of 1976 as a means of providing adequate revenue to the local government. It is local government's share of monies in the Federation account and of the total revenue of the State Government. This share according Oji (2014) is based on a certain formula. In Nigeria, it is $20 \%$ of the Federation Account in addition to $10 \%$ of the State Government's internal revenue. Statutory Revenue Allocation is provided by law making.

As a result, it ensures realistic budgeting and planning. The implication of this is the recognition of the local government, which has statutory and constitutional entitlement to a portion in the Federal Account.

Ibeto (2000) also states that in statutory revenue allocation under the 1979 constitution, The Federal Government is to pay all revenues collected by it into the "Federation Account" except the proceeds from personal income tax of the personnel of the Armed Forces, the police, Ministry of External Affairs, and residents of the Federal Capital Territory. However the problem is that the constitutional arrangement is not followed and abided by the various federating units. The federally generated revenue which are credited to the federation account include the following:

(a) Petroleum profit tax, rents and royalties

(b) Revenue collected by Federal Inland Revenue Department

(C) Customs and Excise duties

(d) Excess to NNPC Account over N100 million (Uche 214) 


\section{Macrothink}

The proceeds of the Federal Account are shared by the federal state and the local government in a ratio that is determined by the operating constitution. This ratio according to 1979 constitution is:

Federal Government - $55 \%$

State Government - $\quad 35 \%$

Local Government - $\quad 10 \%$

Currently under the 1999 constitution, the ratio is:

Federation Account VAT

Federal Government 54.64\% $15 \%$

State Government $\quad 24.72 \% \quad 50 \%$

Local Government $\quad 20.64 \% \quad 35 \%$

This is however, being contested by the State Government. Section 149 of the 1999 constitutions provides that each state shall pay to the Local Government councils in its areas of jurisdiction such proportion of its revenue on such terms and in such manner as may br prescribed by the National Assembly.

\section{Presentation and Analysis of Data}

The aim of the analysis is to test for significant difference between the proportions of responses $\mathrm{P}_{1}$ and $\mathrm{P}_{2}$. Because the sample size was large and the parameter, assumed to be normally distributed, the test concerning that parameter is carried out using the Z-test. It is used in testing the hypotheses Ho: $\mathrm{P}_{1}=\mathrm{P}_{2}$ (i.e. $\mathrm{P}=0.5$ ) as $\mathrm{H} 1: \mathrm{P} 1>0.5$ ). This is obviously a one-tailed test.

$$
\mathrm{Z}=/ \underline{\mathrm{P}_{1}}-\frac{\mathrm{P}_{2}}{\sqrt{\mathrm{Pq}}}
$$

Where

$\mathrm{P}_{1}=$ the proportion of the population that say "yes"

$\mathrm{P}_{2}=$ the proportions of the population that say 'No'

$\mathrm{q}=1-\mathrm{P}$

$\mathrm{P}=0.5$

$\mathrm{n}=$ sample size

10. 1 Test of Hypotheses 


\section{Macrothink}

Ho: There is no relationship between the problem of revenue allocation in Nigeria and the agitation for balanced fiscal federalism.

H1: There is a relationship between the problem of revenue allocation in Nigeria and the agitation for balanced fiscal federalism.

Table 2. Balanced fiscal federalism could only be achieved in Nigeria if federal government adjusts the sharing formula to favour the lower tiers of government?

\begin{tabular}{llll}
\hline & Yes & N o & Total \\
\hline No of respondents & 39 & 18 & 57 \\
Proportion & $0.68\left(\mathrm{P}_{1}\right)$ & $0.32\left(\mathrm{P}_{2}\right)$ & 1.00 \\
\hline
\end{tabular}

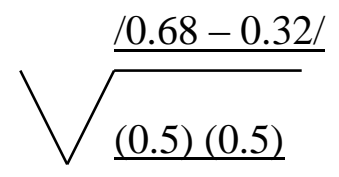

57

$$
=5.4
$$

Using the normal distribution table at a $=0.05$, the tabulated $\mathrm{Z}$ - value is 1.645 , hence one-tailed test for equality of the two ;proportion (i.e. Ho) is rejected in favour of H1.Conclusion therefore, is that $P_{1}$ is significantly greater than $P_{2}$.

\section{Decision}

Since the value of $\mathrm{Z}$ - calculated is greater than the value of $\mathrm{Z}$ - tabulated, the Ho is rejected.

Conclusion: $\mathrm{P}_{1}$ is significantly greater than $\mathrm{P}_{2}$ which means that there is no relationship between problem of revenue allocation in Nigeria and agitation for balanced fiscal federalism in Nigeria.

\section{Hypothesis 2}

Ho: Imperfection in the 1999 constitution of Nigeria has not hampered proper fiscal federalism in Nigeria

H1: Imperfection in the 1999 constitution of Nigeria has hampered proper fiscal federalism in Nigeria

Table 3. Imperfection in the 1999 Constitution hampered proper fiscal federalism in Nigeria

\begin{tabular}{lccccc}
\hline & Strongly agree & Agree & Disagree & Not sure & Total \\
\hline No of respondents & 28 & 19 & 7 & 2 & 58 \\
Proportion & 0.5 & 0.33 & 0.13 & 0.04 & 1.00 \\
\hline
\end{tabular}




\section{Macrothink}

Since there are four responses, the natural thing is to assume, under Ho that the proportion of responses are equal, hence assumption is that $\mathrm{P}=0.25$.

$\mathrm{P}_{1}=0.5, \mathrm{P}_{2}=0.33, \mathrm{P}_{3}=0.13$ and $\mathrm{P}_{4}=0.04$ and compare them each with the population proportion of $\mathrm{P}=0.25$.

For 'Strongly agree'

Ho: the proportion of $\mathrm{P}_{1}$ is 0.25 (i.e. $\mathrm{P}_{1}=\mathrm{p}$ )

$\mathrm{H} 1$ : $\mathrm{P}$ is not equal to 0.25 (i.e. $\mathrm{P}_{1}=\mathrm{P}$ )

Test statistics Z, since sample size is large (i.e>30)

So

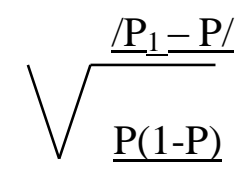

$\mathrm{n}$

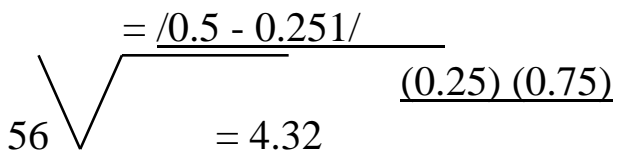

For $\alpha=0.05$, for a two-tailed test, $\mathrm{Z}$ from the normal distribution table is 1.96 .

\section{Decision}

Since the calculated Z (4.32) is greater than the tabulated Z (1.96), Ho is rejected.

Conclusion therefore is $\mathrm{P}_{1 \neq} \mathrm{P}$ hence, sufficient evidence abound that the proportion of respondents who strongly agree is significantly greater than 0.25 .

There is also need to test 'Agree' responses for significant difference from $\mathrm{P}_{1}=0.05$

The procedure is to carry on as before'

$$
\begin{aligned}
& \mathrm{Z}=/ \underline{0.5-0.251} / \\
& \sqrt{\frac{(0.25)(0.75)}{56}}=1.38
\end{aligned}
$$

For $\alpha=0.05$, the tabulated $Z=$ value is 1.96 . Since $Z=-$ calculated is 1.38 which is less than $1.96 \mathrm{~m}$ Ho is accepted. Conclusion is that the proportion who agree to the opinion is not significantly higher than 0.25 .

For 'disagrees' an 'Not sure' opinions, it can be seen that the figures are very small. Considering the result from 0.33 figures an inference can be made that the outcome of the 'disagree' and 'not sure' opinions will not be significantly higher than 0.25 . And this will amount to testing the obvious. 


\section{Macrothink}

Issues in Social Science

ISSN 2329-521X

2016, Vol. 4, No. 2

Conclusion: Since the imperfection in the 1999 constitution in 1999 constitution of Nigeria has hampered proper fiscal federalism in Nigeria, the constitution requires urgent amendment.

\section{Summary of Findings}

The study revealed the following:

(a) Inter-governmental relations has to an extent helped to reduce tension among the three tiers of government in Nigeria.

(b) Inter-governmental relations has led to the duplication of governmental functions and waste of public funds in Nigeria.

(c) Imperfection in the 1999 constitution has hampered proper fiscal relations in the three tiers of government in Nigeria.

\section{Conclusion}

For a Country to attain efficient inter-governmental relations especially as it pertains to fiscal issue is difficult. Efforts being made are just to correct the existing fiscal imbalance. Thus more decentralized governance especially in terms of increase in local government and increased transfer of revenues to lower tiers of government would stimulate economic activities and growth.

\section{Recommendations}

The following recommendations have been preferred:

(a) Effort should be made to ensure that all tiers of government adhere to fiscal transparency, accountability and constitutional provisions on fiscal relations.

(b) Federal government should ensure that all the stakeholders are represented in fiscal federalism that would be permanent.

(c) Efforts should be made to ensure a radical review of the functions of the local government in the constitution. Such review should take cognizance of the responsibilities of the local government and ensure that the funds meant for the local government are released to them on time.

(d) Local government should be given some degree of financial autonomy through the restructuring of the taxation powers.

(e) It is very necessary that National Fiscal Commission is established to enhance intergovernmental understanding and cooperation in ways conducive to dialogue between federal, state and local government actors.

\section{References}

Adedire S. A. (2014). Local Government and Intergovernmental Relation. Nigeria's Fourth Republic Journal of politics and International Affairs, 2(2), 20-32. 


\section{Macrothink}

Anyadike N. O. (2013). New Revenue Sharing formula clamor by the Nigerian State Governors propelling factors and matters. Arising public policy and administration Research, 3(2), 13-24.

Asogwa, N. S. (2009). Intergovernmental Relation, The Nigeria Experience. Enugu: Immaculate Publication Limited.

Bally K. D. (2012). Method of Social Research. London: Collier Macmillan Limited.

Behling, J. H. (2013). Guidelines for Preparing the Research Proposals. New York: University Press of America Inc.

Bello M. L. (2014). Intergovernmental Relations in Nigeria: An assessment of its practice at the Local Government Level. Journal of Poverty, Instrument and Development: An open Access International Journal, 4(1), 11-27.

Borg, Walter R. and Gall M. D (2014). Educational Research; An introduction (4th Ed.). New York: Long Man Inc.

Bowen, B. D., \& Weisberg, H. F. (2014). An introduction To Data Analysis. San Francisco: W.H. Freeman and Company.

Chukwuemeka, E. O. (2006). Research Method and Thesis Writing. A Multi-Disciplinary Approach HRV Publishers.

Danjuma, T. Y. (1994). Revenue Sharing and the Political Economy of Nigerian Federalism. The Nigerian Journal of Federalism, 1(1), 43-68.

Eze, F. U. (2015). The Substance of Local Government in Nigeria, Enugu: Providence Publishers.

Ezeabasili, V. (2006). Fiscal Responsibility Bill 2004 A critical analysis. PhD Seminar in Banking and Finance, Nnamdi Azikiwe University Awka.

Federal Republic of Nigeria (1999). Constitution of the Republic of Nigeria. Lagos: Government Press.

Ibanga, J. (2013). Guide on Tests and Measurement for Teachers and Students. Calabar: Paico Press and Borks Limited.

Ibeto, M. (2000). Intergovernmental Relations in Nigeria: Confusion and Realities. International Journal of Development Studies, 2(1), 33-50.

Kerlinger, F. N. (2014). Foundations of the Behavioural Research (2nd Ed.). San Fransisco: Winston Limited Inc.

Laxmikanth, M (2012). Public Administration for the UPSC Civil Services Preliminary Examination. India: Tata McGraw-Hill Publishing Company Limited.

Nwafor, J. (2009). Intergovernmental Relations. Enugu: Unpublished work.

Nwokedi, R. C. (2002).Power sharing in Nigeria Federation. Enugu: Snaap Press. 


\section{Macrothink}

Nworgu, B. G. (2014). Educational Research: Basic Issues and Methodology. Ibadan: Wisdom Publishers Limited.

Obasi, E. O. (2006). The politics of revenue allocation in Nigeria. Journal of Policy And Development Studies, 2(2), 5-11.

Odo, O. M. (2009). Guide to Proposal writing a Social and Behavioural sciences.Enugu: Snaap Press Limited.

Ogo, I. E. (2007) . Politics of Fiscal Federalism in Nigeria. Journal of Policy and Development Studies , 4(2), 14-21.

Oji, O. (2014). Introduction to Political Science, Enugu: Marydan Publishers.

Okeibe, H. B. (2015). Political Evolution and Constitutional development in Nigeria (1861-1999). Enugu: Mary Dan Press.

Okeke, M., \& Obiora, C. (2010). Intergovernmental Relations and Fiscal Federalism in Nigerian Fourth Republic. Journal of Business and Financial Studies, 1(1), 206-207.

Okoli, F. C., \& Onah, F. (2002) Contemporary Issues in Local Government Administration in Nigeria, Enugu: John Jacobs Classic Publishers

Olugbemi, S. O. (2004). A systems approach to Intergovernmental Relations. Quarterly Journal of Administration, 5(2), 49-70.

Osisioma, B. C., \& Chukwuemeka, E. O. (2007). Intergovernmental Fiscal Relations In Nigeria: A compendium. Nigerian Management Review, 17(2), 15-24.

Silverthorne, C., Fischer, H., \& Fox, D. (2012). The What, When and How of Statistics. San Fransisco: Steps Publishing Company.

Uche, B. (2014). Checks and Balances in Nigeria Local Government System, A Problem, Journal of Policy and Development Studies, 1(1) 22-29.

Ugwu, S. C. (2011). Federal System, The Nigeria Experience. Enugu: Mary Dan Publishers.

Vincent, O. (2002). The politics of Revenue allocation in Nigeria. Journal of Banking and Finance, 2(2), 5-9.

Williams, F. (2015). Reasoning with Statistics (2nd Ed.). San Fransisco: Holt, Rinehart and Winston Inc. 